\title{
VERBALIZATION OF THE CONCEPT \\ OF FEAR IN THE ENGLISH YOUTH DYSTOPIAN NOVEL “THE MAZE RUNNER" BY JAMES DASHNER
}

Shkuta O. H.

\section{INTRODUCTION}

The problem of verbal reflection of holistic view of the world in the human mind, represented by linguistic means, seems to be one of the most burning issues of cognitive linguistics. The focus of cognitive linguists ${ }^{1,2,3,4,5}$ is the means of modeling the content and structure of individual concepts as units of writer's consciousness, which is called the conceptoshere ${ }^{3}$.

Due to the fact that artistic concept ${ }^{4}$ is considered to be a unit of the writer's consciousness, which is verbalized in an artistic work or a combination of works and expresses an individual author's understanding of the essence of objects and phenomena, the representation of a concept in fictional texts is unique and individual.

The author's emotional linguistic picture of the world reflects a certain way of conceptualization of reality and is defined as a set of emotional representations, emotional notions, emotional concepts, which create, via

1 Чезыбаева Н.В. Семантически сопряженные концепты СТРАХ и БЕССТРАШИЕ. Вестник Воронежского государственного университета. 2011. № 1. C. 113-117. URL: https://cyberleninka.ru/article/n/semanticheskisopryazhennye-kontsepty-strah-i-besstrashie/viewer (дата звернення 18.12.2020)

${ }^{2}$ Шкута О.Г. Вербалізація концепту СТРАХ в англійськомовному молодіжному антиутопічному романі Сюзанни Коллінз “The Hunger Games”. Вісник Київського національного лінгвістичного університету. 2019. № 22 (2). C. 79-87. DOI: 10.32589/2311-0821.2.2019.192338.

${ }^{3}$ Красавский Н.А. Концепты СТРАХ и ЖЕСТОКОСТЬ в новелле Франца Кафки «Превращение». Филологические науки. Вопросы теории и практики. 2016. C. 100-103. URL: https://cyberleninka.ru/article/n/kontsepty-strah-i-zhestokost-v-novellefrantsa-kafki-prevraschenie/viewer (дата звернення: 18.12.2020).

4 Солидолова И.А. Проблема моделирования эмоциональных концептов. Вестник Башкирского университета. 2010. URL: https://cyberleninka.ru/article/n/ problemy-modelirovaniya-emotsionalnyh-kontseptov/viewer (дата звернення: 18.12.2020).

5 Щербакова И.В. Реализация концепта CTPAX (ANGST) в немецком языке. Символ науки. 2016. № 3. С. 150-152. URL: https://cyberleninka.ru/article/n/ semanticheski-sopryazhennye-kontsepty-strah-i-besstrashie/viewer (дата звернення: 18.12.2020). 
verbalization, complex semantic phenomena possessing a certain structure. The linguistic way of the conceptualization of reality is universal and nationally specific at the same time, which is also manifested in the verbalization of emotions ${ }^{6}$.

It is assumed ${ }^{7}$ that there exist certain "emotional imprint" in a fictional text that evokes particular emotions of a reader. Emotional space of a fictional text is a well-organized part of its structure, which is conditioned by its structural and functional quality and can provoke a dynamic continuum of emotions in the process of perception.

Emotional concepts are an integral part of the structured experience of some elements of the emotional sphere of consciousness, which form a separate layer of the conceptual picture of the world and are expressed verbally in a fictional text as cognitive representations of emotions. Interest in the study of emotion nominations is determined by their socio-cultural and psychophysical significance, as well as by their abstract nature, which is difficult to analyze ${ }^{8}$.

The subject of my study is the emotional concept of FEAR. The analysis of emotional concepts aims to show that emotions as a phenomenon of the psyche have an extremely complex conceptual structure. Being an integral component of spiritual culture, emotions, for all their universalism, have certain peculiar features in the works of different authors, due to the subjective interpretation of the surrounding reality.

Thus, the aim of the article is to define the means of verbalization of the concept of FEAR. The choice of the concept of FEAR in the youth dystopian novel The Maze Runner by James Dashner as the material of investigation is not random: the given concept appears to be a leitmotif of the work and is represented diversely throughout the novel. The following methods are applied to analyze the data: descriptive method - to form a theoretical base of the research, lexicographic sources and vocabulary definitions analysis for the semantization and explication of the language units, explication method - to analyze and combine common national and author's individual view of the world, method of sense interpretation of the content - to

${ }^{6}$ Prihodko G.I. Frame structure of the evaluative utterance. Messenger of Kyiv National Linguistic University. 2019. № 22 (2). P. 115. DOI: 10.32589/23110821.2.2019.192447.

Красавский Н.А. Эмоциональные концепты в немецкой и русской лингвокультурах. Москва, 2008. С. 168.

8 Чезыбаева Н.В. Семантически сопряженные концепты СТPAX и БЕССТРАШИЕ. Вестник Воронежского государственного университета. 2011. № 1. C. 113-117. URL: https://cyberleninka.ru/article/n/semanticheski-sopryazhennyekontsepty-strah-i-besstrashie/viewer (дата звернення: 18.12.2020). 
compare genetically identical concepts, conceptual analysis - to model and describe the concept of FEAR.

Chezybaeva $^{9}$ states that FEAR, the feeling of horror, is an emotional multiaspectual concept related to psychology, sociology and linguistics. Determining the place of fear in the system of human emotions, we adhere to the definition of this emotion as a mental process that reflects a person's attitude to himself/herself and the world around him/her, characterized by mimic, psychosomatic and behavioral changes. Fear, although it is an emotion inherent in all people, takes various forms and, accordingly, ways of expression in different cultures. From the standpoint of individual author's consciousness, this concept appears to be the most unpredictable and vivid phenomena, which is a reflection of the author's mentality and his/her personal characteristics, inclinations and worldview ${ }^{10}$.

\section{The concept of FEAR. Emotional concepts as an integral part of the author's conceptosphere}

Cognitive linguistics is a part of the philosophical direction of cognitivism, the main aim of which is to study man as a system of information processing and explain his/her behavior in terms of internal states. To answer questions about the nature of reason, the comprehension of experience, and the organization of conceptual systems, cognitive linguists conduct research at the intersection of the following sciences: psychology, philosophy, anthropology, and linguistics ${ }^{11}$.

Cognitive linguistics studies the processing of linguistic information for building models that mimic human behavior. Its origin dates back to the late 50 's of the twentieth century, when the idea that linguistic facts can be at least partly explained by phenomena of a non-linguistic nature, and not necessarily observable, emerged ${ }^{12}$. Various researchers have called them

9 Чезыбаева Н.В. Семантически сопряженные концепты СТРАХ и БЕССТРАШИЕ. Вестник Воронежского государственного университета. 2011. № 1. C. 113-117. URL: https://cyberleninka.ru/article/n/semanticheski-sopryazhennyekontsepty-strah-i-besstrashie/viewer (дата звернення: 18.12.2020).

10 Щербакова И.В. Реализация концепта CTPAX (ANGST) в немецком языке. Символ науки. 2016. № 3. С. 150-152. URL: https://cyberleninka.ru/article/n/ semanticheski-sopryazhennye-kontsepty-strah-i-besstrashie/viewer (дата звернення: 18.12.2020).

11 Кузнецова Н.В., Перетокина В.А. Лингвистическая реализация концепта НЕНАВИСТЬ. Вестник Нижегородского университета им. Н.И. Лобачевского. 2011. № 6 (2). C. 349-352. URL: https://cyberleninka.ru/article/n/lingvisticheskayarealizatsiya-kontsepta-nenavist/viewer (дата звернення: 18.12.2020).

12 Паршин П.Б. Теоретические перевороты и методологический мятеж в лингвистике XX века. Вопросы языкознания. 1996. № 2. С. 27. 
"frames", "idealized cognitive models", "mental space", "caption", and in our time they are reflected in the conceptual theory ${ }^{13,14,15}$.

Despite close attention paid to the study of the notion of concept, it has not still been given a clear and unambiguous definition due to various reasons: some scientists believe that one of the main reasons is an inseparability of conceptual structure and its abstract nature ${ }^{16}$; others state that the compositional structure of concepts is heterogeneous, and the difficulties are caused by the principles of compatibility and combination ${ }^{17}$.

Each person has an individual cultural experience and a stock of knowledge and skills that determine the richness of the meanings of the word and the variety of concepts of these meanings, and in some cases their poorness and uniqueness ${ }^{18}$. Concept is the sum of the experience of a linguistic personality and lexical meaning of a word ${ }^{19}$. It is closely connected with the mental world of an author, therefore its character is very specific.

The notion of concept is a mental structure which is present in a collective or individual linguistic consciousness and an invariant meaning of an associative-semantic field ${ }^{20}$. This mental-linguistic complex may have not only verbal, but also non-verbal representations, has a basically stable correlation of the core and periphery of the associative-semantic field, is

13 Ченки А. Семантика в когнитивной лингвистике. Фундаментальные направления современной американской лингвистики / под ред. А.А. Кибрика, И.М. Кобозевой, И.А. Секериной. Москва : МГУ, 1997. 369 с.

14 Солодуб Ю.П. Современный русский язык : Лексика и фразеология (сопоставительный аспект). Москва, 2002. 259 с.

15 Попова З.Д., Стернин И.А. Очерки по когнитивной лингвистике. Москва, 2007. $288 \mathrm{c}$.

16 Солидолова И.А. Проблема моделирования эмоциональных концептов. Вестник Башкирского университета. 2010. URL: https://cyberleninka.ru/article/n/ problemy-modelirovaniya-emotsionalnyh-kontseptov/viewer (дата звернення: 18.12.2020).

17 Красавский Н.А. Концепты СТРАХ и ЖЕСТОКОСТЬ в новелле Франца Кафки «Превращение». Филологические науки. Вопросы теории и практики. 2016. C. 100-103. URL: https://cyberleninka.ru/article/n/kontsepty-strah-i-zhestokost-v-novellefrantsa-kafki-prevraschenie/viewer (дата звернення: 18.12.2020).

18 Кузнецова Н.В., Перетокина В.А. Лингвистическая реализация концепта НЕНАВИСТЬ. Вестник Нижегородского университета им. Н.И. Лобачевского. 2011. № 6 (2). C. 349-352. URL: https://cyberleninka.ru/article/n/lingvisticheskayarealizatsiya-kontsepta-nenavist/viewer (дата звернення: 18.12.2020).

19 Шаховский В.И. Эмоциональные культурные концепты : параллели и константы. Волгоград ; Архангельск, 1996. С. 81.

${ }^{20}$ Щербакова И.В. Реализация концепта CTPAX (ANGST) в немецком языке. Символ науки. 2016. № 3. С. 150-152. URL: https://cyberleninka.ru/article/n/ semanticheski-sopryazhennye-kontsepty-strah-i-besstrashie/viewer (дата звернення: 18.12.2020). 
oriented to pragmatic information and is similarly represented in the linguistic world view of an author ${ }^{21}$.

Conceptualization is a mental processes that correlates information from different areas of human experience ${ }^{22}$, structures it, and aims to identify minimal units of the experience ${ }^{23}$, which results in definition of concepts as mental units, the function of which is to storage knowledge about the world ${ }^{24}$.

Linguistic concept is understood as a cognitive (i.e., related to consciousness, not reality) phenomenon, uniting many verbalized and nonverbalized meanings, one way or another related to the object of reality ${ }^{25}$. The presence of non-verbal meanings in the content of a concept distinguishes it from a concept whose content consists only of verbalized meanings.

Thus, the concept is defined as a thought that reflects "in a generalized form the objects and phenomena of reality by fixing their properties and relations; the latter - properties and relations - appear in the concept as general and specific features, correlated with the classes of objects and phenomena"26. Thus, the sense is a part of the content of a concept, including verbalized meanings, generalizing the properties of the object as a result of their categorization ${ }^{27}$. Consciousness of a meaning in the content of a linguistic concept is possible only through the expression of this meaning via a linguistic sign. The linguistic signs verbalizing the meanings of a concept can refer to different levels of language, i.e. the same concept can have morphological, lexical or syntactic expression, as well as expressed in

21 Яшкина Е.А. Языковая репрезентация языкового концепта СТРАХ в диахроническом аспекте. Наука $u$ современность. 2011. URL: https://cyberleninka.ru/article/n/yazykovaya-reprezentatsiya-emotsionalnogo-kontseptastrah-v-diahronicheskom-aspekte/viewer (дата звернення: 18.12.2020).

${ }^{22}$ Langacker R.W. A view of linguistic semantics. Topics in Cognitive Linguistics. 1988. P. 74.

${ }^{23}$ Шафиков С.Г. Любовь: Категория или концепт? Языковые и речевые единицы в разных языках. 2006. С. 23.

${ }^{24}$ Schwarz M. Einführung in die kognitive Linguistik, überarb. und aktualisierte aufl. Tübingen ; Basel : Francke, 1996. P. 135.

${ }_{25}$ Смурова О.В. Модель лингвистического концепта как композиция функций отображения. Вестник Московского государственного лингвистического университета. 2014. № 25 (711). C. 20-29. URL: https://cyberleninka.ru/article/n/ model-lingvisticheskogo-kontsepta-kak-kompozitsiya-funktsiy-otobrazheniya/viewer (дата звернення: 18.12.2020).

26 Лингвистический энциклопедический словарь. Москва : Советская энциклопедия, 1990. С. 383-384.

27 Демьянков В.З. Когниция и понимание текста. Bonpocы когнитивной лингвистики. 2005. № 3. С. 5. 
super-phrase units, some meanings of the concept can be conveyed by nonverbal means. Each individual verbalization of the concept highlights a certain set of meanings included in the concept. In this sense, the more verbalizations we associate with the concept, the more meanings included in the concept we can reveal ${ }^{28}$.

An artistic concept, in contrast to the "non-artistic" (universal concept), is a mental structure that has also undergone semiosis and is recognized as an invariant meaning of an associative-semantic field, but present in the individual consciousness of a creator ${ }^{29}$.

The notion of concept is wider than the notion of linguistic meaning, most researchers agree that the appearance of the concept is based on a sensual image, and the meaning of a word is considered to be a set of semantic components, i.e. seme ${ }^{30}$.

During semantic analysis, general number of the semes cannot represent the content of the concept as a whole, in other words, the thread of thoughts never finds a comprehensive expression in a verbal form ${ }^{31}$. The concept is considered to be a unit of the conceptosphere (area of thoughts consisting of concepts) ${ }^{32}$, and the meaning is a unit of the language semantic space (a part of the conceptosphere, which is realized via signs), the semantic system ${ }^{33}$. With the help of its semes the meaning conveys certain signs that create concept, but express only a part of its semantic content ${ }^{32}$.

${ }^{28}$ Слышкин Г.Г. Лингвокультурные концепты прецедентных текстов. Москва, 2000. C. 98.

29 Чезыбаева Н.В. Семантически сопряженные концепты СТРАХ и БЕССТРАШИЕ. Вестник Воронежского государственного университета. 2011. № 1. C. 113-117. URL: https://cyberleninka.ru/article/n/semanticheski-sopryazhennyekontsepty-strah-i-besstrashie/viewer (дата звернення: 18.12.2020).

30 Кузнецова Н.В., Перетокина В.А. Лингвистическая реализация концепта НЕНАВИСТЬ. Вестник Нижегородского университета им. Н.И. Лобачевского. 2011. № 6 (2). C. 349-352. URL: https://cyberleninka.ru/article/n/lingvisticheskayarealizatsiya-kontsepta-nenavist/viewer (дата звернення: 18.12.2020).

31 Яшкина Е.А. Языковая репрезентация языкового концепта СТPAX в диахроническом аспекте. Наука $u$ современность. 2011. URL: https://cyberleninka.ru/article/n/yazykovaya-reprezentatsiya-emotsionalnogo-kontseptastrah-v-diahronicheskom-aspekte/viewer (дата звернення: 18.12.2020).

${ }^{32}$ Харченко В.К. Скрытые концепты народных примет. Вопросы журналистики, педагогики, языкознания. 2010. № 18 (89). C. 65-72. URL: https://cyberleninka.ru/article/n/skrytye-kontsepty-narodnyh-primet/viewer (дата звернення: 18.12.2020).

Чезыбаева Н.В. Семантически сопряженные концепты СТРАХ и БЕССТРАШИЕ. Вестник Воронежского государственного университета. 2011. № 1. C. 113-117. URL: https://cyberleninka.ru/article/n/semanticheski-sopryazhennyekontsepty-strah-i-besstrashie/viewer (дата звернення: 18.12.2020). 
Conceptualization of emotions, the relationship of emotions and cognition, and description of emotional concepts are the issues, which cause heated debate among the researchers. Emotions occupy an important place in the conceptosphere of any national language. They are a sociocultural phenomenon that performs many functions, including cognitive ${ }^{34}$.

Analysis of emotional concepts has recently become one of the most developed areas in linguoconceptology. As a consequence, there exist an increased interest of researchers to the problem of relationship between language and emotions, the conceptualization of emotions in different linguistic cultures ${ }^{35}$.

Emotions are viewed as "mental reflection in the form of direct biased understanding of the meaning of phenomena and situations, due to the reference of their objective properties to the needs of the subject" ${ }^{36}$. Emotions are also a "specific form of human attitude to reality and its linguistic (and proto-linguistic) expression (interpretation)",37.

There exist five stages in the development of emotions:

1. The source of emotion is usually the physical or mental perception of a certain state of affairs.

2. The direct cause of emotion is usually an intellectual assessment of the state of affairs as probable or unexpected, desirable or undesirable for the subject $^{38}$.

3. The emotion itself, or state of mind, conditioned by the state of affairs, which is perceived by a person, and his/her intellectual assessment of the state of affairs.

4. The desire caused by this or that intellectual estimation or the emotion itself to prolong or stop existence of the reason which causes the emotion.

34 Солидолова И.А. Проблема моделирования эмоциональных концептов. Вестник Башкирского университета. 2010. URL: https://cyberleninka.ru/article/n/ problemy-modelirovaniya-emotsionalnyh-kontseptov/viewer (дата звернення: 18.12.2020).

35 Бульбенко Е.С. Базовые составляющие эмоциональных концептов КОВАРСТВО и ХИТРОСТЬ. Известия Волгоградского государственного педагогического университета. 2011. С. 27. URL: https://cyberleninka.ru/article/n/ bazovye-sostavlyayuschie-emotsionalnyh-kontseptov-kovarstvo-i-hitrost/viewer (дата звернення: 18.12.2020).

36 Красавский Н.А. Эмоциональные концепты в немецкой и русской лингвокультурах. Москва, 2008. С. 298.

37 Шаховский В.И. Эмоциональные культурные концепты : параллели и константы. Волгоград ; Архангельск, 1996. С. 385.

${ }^{38}$ Барсукова И.В. Систематизация лингвистических концептов эмоциональных состояний. Вестник Самарского государственного университета. 2008. № 4 (63). C. 13-18. URL: https://cyberleninka.ru/article/n/sistematizatsiya-lingvisticheskihkontseptov-emotsionalnyh-sostoyaniy/viewer (дата звернення: 18.12.2020). 
5. External manifestation of emotion ${ }^{39}$.

Emotions possess communicative function, because with their help certain information is transmitted through an external expression of feelings - both verbally and nonverbally ${ }^{40}$.

The nominee of emotion is understood as a substantively designed verbal sign denoting emotion, i.e. the basic nominee of emotion is a word, denoting, respectively, the basic emotion ${ }^{41}$. In fictional literature, the nominees of emotions are associated with the description of the inner emotional states of a man, his/her feelings and experiences ${ }^{40}$.

Emotional concept is understood as "ethnically, culturally conditioned, complex structural-semantic, as a rule, lexically and / or phraseologically verbalized unit based on a conceptual foundation, which includes, in addition to the concept, image and evaluation, and functionally replaces single-order objects (in the broadest sense of the word), in the process of reflection and communication, causing a biased attitude towards them" ${ }^{\text {" }}$.

Emotional concepts are the result of a complex cognitive and emotional development of linguistic and non-linguistic activity. Linguistic nominations of emotions create a large field for research in the linguistic and cultural synchronic and diachronic aspect ${ }^{42}$. It seems difficult to find answers to the questions concerning the identification of a linguospecific structure of emotional concepts, as important extralinguistic factors that affect the human emotional sphere remain out of the field of view of researchers. The study of the essence of cultural emotional concepts of the language material allows to describe the content of fragments of the emotional lexical-semantic field through the use of linguistic techniques ${ }^{43}$.

${ }^{39}$ Апресян Ю.Д. Избранные труды. Москва : Школа «Языки русской культуры», 1995. Т. 2. С. 116.

40 Андронкина Н.М., Голованова Е.Г. Эмоциональные концепты в обучении иноязычному межкультурному общению. Мир науки, культуры, образования. 2012. № 2 (33). C. 28-32. URL: https://cyberleninka.ru/article/n/emotsionalnye-kontsepty-vobuchenii-inoyazychnomu-mezhkulturnomu-obscheniyu/viewer (дата звернення: 18.12.2020).

41 Красавский Н.А. Эмоциональные концепты в немецкой и русской лингвокультурах. Москва, 2008. С. 236.

42 Красавский Н.А. Концепты СТРАХ и ЖЕСТОКОСТЬ в новелле Франца Кафки «Превращение». Филологические науки. Вопросы теории и практики. 2016. C. 100-103. URL: https://cyberleninka.ru/article/n/kontsepty-strah-i-zhestokost-v-novellefrantsa-kafki-prevraschenie/viewer (дата звернення: 18.12.2020)

43 Чесноков И.И. Месть как эмоциональный поведенческий концепт (опыт когнитивно-коммуникативного описания в контексте русской лингвокультуры) : монография. Волгоград : Изд-во ВГПУ «Перемена», 2008. С. 202. 
The subject of our study is the emotional concept of FEAR. While analyzing the structure of the concept the three basic components should be taken into consideration: conceptual, value and figurative ${ }^{44}$.

FEAR is one of the most basic concepts of reality. Fear, as anger, sadness and satisfaction, is one of four basic emotions of a person. Thus, the cultural component of relations caused by a sense of fear cannot go unnoticed. Fear is an important component of the culture of any society ${ }^{45}$. Therefore, it seems interesting to trace how this complex phenomenon is conceptualized in the consciousness of a fictional text author.

\section{The concept of FEAR in the English youth dystopian novel The Maze Runner by James Dashner}

The concept of FEAR is a concept of an abstract name, it is not fixed, fluid, more individual than the concepts of specific names and is determined by the moral standards and traditions of particular society. According to the I.V. Shcherbakova ${ }^{46}$, the core of the concept is most fully reflected by the semantics of the keyword, i.e. name of the concept ${ }^{46}$.

In this article the nominees for the concept of FEAR in the novel The Maze runner ${ }^{47}$ by James Dashner are considered. It is verbalized in the novel by such primary concept nominees as horror, terror, fear, frightened, to scare, scared, to dread, etc.:

Thomas was struck with an odd mix of horror and embarrassment ${ }^{47}$.

He felt such a mixture of emotions - curiosity, frustration, wonder - all laced with the lingering horror of seeing the Griever that morning ${ }^{47}$.

His eyes were open, and they were wide with terror ${ }^{47}$.

Filled with terror at what the consequences might be $e^{47}$.

For the first time, Thomas felt anger creeping in to compete with his fear and panic $^{48}$.

He fought the fear, forced his body to remain perfectly still, hanging there in the vines ${ }^{48}$.

\footnotetext{
${ }^{44}$ Карасик В.И. Языковой круг : личность, концепты, дискурс. Волгоград, 2002. C. 105.

45 Яшкина Е.А. Языковая репрезентация языкового концепта CTPAX в
} диахроническом аспекте. Наука и современность. 2011. URL: https://cyberleninka.ru/ article/n/yazykovaya-reprezentatsiya-emotsionalnogo-kontsepta-strah-v-diahronicheskomaspekte/viewer (дата звернення: 18.12.2020).

46 Щербакова И.В. Реализация концепта CTPAX (ANGST) в немецком языке. Символ науки. 2016. № 3. C. 150-152. URL: https://cyberleninka.ru/article/n/ semanticheski-sopryazhennye-kontsepty-strah-i-besstrashie/viewer (дата звернення: 18.12.2020).

${ }^{47}$ Dashner J. The Maze Runner. New York, 2009. P. 21, 29, 55, 69.

${ }^{48}$ Dashner J. The Maze Runner. New York, 2009. P. 71, 76, 127, 146, 125, 156, 159, 191, 31, 61, 156. 
In truth, as Thomas silently watched the commotion, he didn't feel nearly as panicked or frightened as his instincts told him he ought to be ${ }^{48}$.

Thomas turned to see who'd opened the door, expecting a frightened Chuck or maybe a reconsidering Alby ${ }^{48}$.

And we don't know what that word means - probably just something to scare $u s^{48}$.

Thomas was eager to do so, but was also scared to death it might end up being nothing ${ }^{48}$.

Even though he was nervous and scared, he told Minho he could take one of the sections himself, but the Keeper refused ${ }^{48}$.

What courage he'd gathered had turned to dread, and he wondered when the Grievers would finally give chase ${ }^{48}$.

Phraseological units also refer to the units of description objectifying the emotion of fear or terror. Kharchenko ${ }^{49}$ states that the cultural and national experience of the nation is reflected through the paremic ideas and, accordingly, the specifics of perception and understanding of the concept under study are fixed in them.

In The Maze Runner, descriptive nominees of the concept of FEAR include phraseological units, such as: to give sb a chill, to be scared to death, etc. E.g.

This thought gave him a chill, made him wonder if a Griever might come charging toward them at any minute ${ }^{48}$.

Still gives me the chills thinkin' I might have gone through the Changing ${ }^{48}$.

Thomas was eager to do so, but was also scared to death it might end up being nothing ${ }^{48}$.

Which is why I'm scared to death that what we're about to do is a whole pile of stupid ${ }^{50}$.

In addition to the direct nomination of the given concept I have revealed a group of lexical units verbalizing physiological manifestations (non-verbal markers) of fear. This is due to the fact that the concept of FEAR is based on the emotion of fear, terror, horror, manifested by "intonational and prosodic" and "kinesic" (facial expressions, gestures, poses) means. These markers initially have a psychophysical nature, but, being significant characteristics of emotions, are fixed in the language, mainly in the form of

49 Харченко В.К. Скрытые концепты народных примет. Вопросы журналистики, педагогики, языкознания. 2010. № 18 (89). C. 65-72. URL: https://cyberleninka.ru/article/n/skrytye-kontsepty-narodnyh-primet/viewer (дата звернення: 18.12.2020).

${ }^{50}$ Dashner J. The Maze Runner. New York, 2009. P. 187, 186, 90, 192, 206, 39, $71,97,17$. 
metaphorical units ${ }^{51}$. The following examples from the novel The Maze Runner illustrate the use of the means of verbalization of non-verbal markers of fear by the author:

Chuck had tried to act brave from the time he first found out they were going for it, but his sweaty skin and dazed eyes revealed the truth ${ }^{50}$.

The next morning, Thomas found himself sitting in a chair, worried and anxious, sweating, facing eleven other boys ${ }^{50}$.

Thomas was pressed between Newt and Teresa - he could feel Newt trembling ${ }^{50}$.

He let go of Chuck, stood up, trembling, turned to face their new visitors ${ }^{50}$.

Thomas's gut clenched ${ }^{50}$.

"Ah, man, oh man", Minho whispered, then crumpled to the ground, burying his face in clenched fist $^{50}$.

In the process of reconstructing of the conceptual layer of the concept of FEAR, I have taken into consideration that artistic meaning is directly related to the author's intention and is characterized by a considerable degree of individuality, if compare with its denotative meaning given in the dictionary. Based on the definitions of the word fear given by E.A. Yashkina ${ }^{52}$, I have grouped the samples with the word fear taken from the novel by James Dashner:

1. An intensive feeling of fear, shock or disgust:

Fear, loneliness, desperation, sadness, even the slightest hint of joy ${ }^{53}$.

Thomas barely heard him, shocked by how much bigger it was up close ${ }^{53}$. But he was also disgusted with himself for being so shallow and glib ${ }^{53}$.

2. A thing causing a fear or horror:

The idea hadn't occurred to him before, but would it be worth it to get stung by the Grievers, go through that horrible process, just to remember something ${ }^{53}$ ?

He'd been through the whole gamut of emotions in the short time since he'd arrived at the Glade ${ }^{53}$.

51 Красавский Н.А. Концепты СТРАХ и ЖЕСТОКОСТЬ в новелле Франца Кафки «Превращение». Филологические науки. Вопросы теории и практики. 2016. C. 100-103. URL: https://cyberleninka.ru/article/n/kontsepty-strah-i-zhestokost-v-novellefrantsa-kafki-prevraschenie/viewer (дата звернення: 18.12.2020).

52 Яшкина Е.А. Языковая репрезентация языкового концепта СТРАХ в диахроническом аспекте. Наука и современность. 2011. URL: https://cyberleninka.ru/ article/n/yazykovaya-reprezentatsiya-emotsionalnogo-kontsepta-strah-v-diahronicheskomaspekte/viewer (дата звернення: 18.12.2020).

${ }^{53}$ Dashner J. The Maze Runner. New York, 2009. P. 97, 17, 44, 97, 208, 211, 29, 45, $135,149,202,72$. 
Several men and women dressed in grimy jeans and soaking-wet coats burst through the entrance with guns raised, yelling and screaming words over each other ${ }^{53}$.

3. A literary of film genre concerned with arousing feelings of fear:

Horror grew in his heart ${ }^{53}$.

He felt such a mixture of emotions - curiosity, frustration, wonder-all laced with the lingering horror of seeing the Griever that morning ${ }^{53}$.

It seemed like a monster, a horror from a nightmare, but Thomas knew it had to be a Glader, someone who'd completely lost his mind ${ }^{53}$.

4. Intense dismay:

She looked so different now, awake and alert-standing ${ }^{53}$.

Thomas could only worry about Minho ${ }^{53}$.

Panic gripped Thomas's heart ${ }^{53}$.

5. Extreme dislike:

A sudden dislike for the guy swelled up inside him. Minho was a veteran in this place, a Runner ${ }^{53}$.

He couldn't remember much, but something told him he'd never disliked someone so strongly ${ }^{54}$.

He looked like he didn't believe a word Thomas said, seemed almost angry $^{54}$.

The study has shown that the first dictionary and the most common meaning of the lexeme "fear" is the most relevant for James Dashner. I have determined that through the novel the author uses the corresponding lexeme rather often, and, as the analysis of the substantive components of the described concept has shown, the main cognitive signs representing this concept are external manifestations of fear - facial and eyes expressions, gestures, etc. E.g.:

You won't figure out anything if you give in to fear ${ }^{54}$.

The fear was like icy dew on his skin ${ }^{54}$.

Each step groaned and creaked under his weight; he might've stopped for fear of falling through the old wood if he weren't leaving such an awkward situation below ${ }^{54}$.

Thomas's eyes widened, and another boy stepped up and playfully slapped Alby across the head ${ }^{54}$.

He stilled, felt his eyes widen, his breathing stop for a long moment ${ }^{54}$.

Thomas realized his own mouth had dropped wide open ${ }^{54}$.

Thomas felt his mouth drop open ${ }^{54}$.

${ }^{54}$ Dashner J. The Maze Runner. New York, 2009. P. 22, 37, 8, 11, 14, 9, 23, 95, 205, $36,45,67,85,191$. 
It should be noted that the concept of FEAR in the English youth dystopian novel The Maze Runner by James Dashner is used in the meaning of fear and horror:

But the thing that had really stood out to him was her skin: pale, white as pearls $^{54}$.

He saw only a flash of pale skin and enormous eyes - the haunted image of an apparition-and cried out, tried to run, but it was too late ${ }^{54}$.

Thomas looked over at Chuck, who seemed as pale-faced as Newt ${ }^{54}$.

Minho looked over at him, a blank expression on his face ${ }^{54}$.

Thomas shook his head, trying to squash the terror Minho's expression had given him ${ }^{54}$.

Chuc's eyes widened, as if the darkest, deepest secret of the universe had just been revealed to him $^{55}$.

Having analyzed The Maze Runner novel, I have found out that one of the main principles of James Dashner's work is the desire to intrigue the reader, effect them and keep their attention till the very end, maintaining the dynamism of the story. I believe that the author would not have achieved a similar effect, if he had resorted to a detailed description of the experiences of the characters. Furthermore, it should be mentioned that he follows the principle of "efficiency". However, this is by no means, evidence of the superficialness of James Dashner's work, which some critics accuse him of. The illustrative material of my research shows that the use of the technique of description of the characters' experience is the right decision to impress the reader, as well as to fulfill the plot with imagery and deep meaning. E. g.:

Thomas screamed, but he kept running until they made it to the Cliff ${ }^{55}$.

He screamed, called for help, pounded on the walls with his fists ${ }^{55}$.

Thomas stared in horror at the monstrous thing making its way down the long corridor of the Maze $e^{55}$.

Minho didn't wait for a response, didn't see the look of horror Thomas had just felt widen his own eyes ${ }^{55}$.

Psychological research, published in the Encyclopedia of Practical Psychology $y^{56}$, approves that fright cannot be considered a feeling or emotion, but mostly "reflectory reaction of a body". The feeling of fright is a change in the entire functional state of a person, their body, mind and soul. In a dangerous situation, a person may experience "reflexive autonomic reactions in the form of fright (fear)", but they will remain internally calm

${ }^{55}$ Dashner J. The Maze Runner. New York, 2009. P. 128, 197, 5, 76, 129, 140.

56 Красавский Н.А. Концепты СТРАХ и ЖЕСТОКОСТЬ в новелле Франца Кафки «Превращение». Филологические науки. Вопросы теории и практики. 2016. C. 100-103. URL: https://cyberleninka.ru/article/n/kontsepty-strah-i-zhestokost-v-novellefrantsa-kafki-prevraschenie/viewer (дата звернення: 18.12.2020). 
and decisive. However, a sense of fear rather often follows fright that results in confusion of notions. Let's compare the following examples: 1) Thomas helped as the Builders gathered every loose item they could find and piled them in the gaps, nailing things together as best they could. It looked ugly and pathetic and scared him to death - no way that'd keep the Grievers out $^{57}$; 2) He dreaded going back to work with Winston the Butcher and knew he needed to eat lunch, but he didn't want to be near anybody for as long as he could get away with $i^{57}$.

In the first sample, the described character experiences a feeling of fright, and changes have occurred in his emotional and functional state. However, in the first example we cannot speak about fright in its common sense, there is no fear in itself. The writer does not want something to happen, and the lexeme dread indicates that there were no real changes in his emotional state.

Psycholinguists $^{58}$ also note that one of the behavioral patterns in a situation of experiencing fear is behavior similar to that of animals in a dangerous situation - freezing when "the animal seeks to become as inconspicuous as possible to merge with the surrounding landscape. To do this, it stops any activity and slows the breathing down. In a dangerous situation, a person is also afraid to move or breathe so as not to give

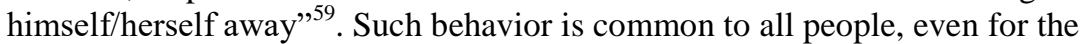
characters of the James Dashner's novel, and is expressed through a frequent use of static lexemes. An example of this statement is the following sentences: Fear, loneliness, desperation, sadness, even the slightest hint of $j^{5} y^{57}$. A long pause stretched into several minutes, and Thomas's hands shook with fear ${ }^{57}$. Thomas looked up in horror. The creatures on both sides of their group seemed to have noticed them again ${ }^{57}$.

"To be filled with fear/horror/terror" and "the ability to overcome it" are the most important characteristics of the concept. They are nuclear and are inherent in a picture of the world of entire nations, and so of their individual representatives. E. g.:

Thomas did, reciting every word he'd told the Keepers, hating how Teresa's eyes filled with worry-and terror ${ }^{57}$.

${ }^{57}$ Dashner J. The Maze Runner. New York, 2009. P. 140, 54, 97, 101, 194, 184, 46, 69.

58 Кузнецова Н.В., Перетокина В.А. Лингвистическая реализация концепта НЕНАВИСТЬ. Вестник Нижегородского университета им. Н.И. Лобачевского. 2011. № 6 (2). C. 349-352. URL: https://cyberleninka.ru/article/n/lingvisticheskayarealizatsiya-kontsepta-nenavist/viewer (дата звернення: 18.12.2020).

59 Чезыбаева Н.В. Семантически сопряженные концепты СТPAX и БЕССТРАШИЕ. Вестник Воронежского государственного университета. 2011. № 1. C. 113-117. URL: https://cyberleninka.ru/article/n/semanticheski-sopryazhennyekontsepty-strah-i-besstrashie/viewer (дата звернення: 18.12.2020). 
Thomas was filled with a queasy fear, disbelief that this was happening at all $^{57}$.

Filled with terror at what the consequences might be $e^{57}$.

Somehow, he had to get back to the ground, or it would all end quickly ${ }^{60}$.

Thomas couldn't stop wondering about how the Grievers' enraged cries had ended as they fell from the Cliff, and how he hadn't been able to see them plummeting to their deaths ${ }^{60}$.

We somehow got it into our klunk heads that once the Doors closed, you were done - end of story ${ }^{60}$.

Now, I turn your attention to the analysis of cognitive characteristics of the concept under analysis. In the course of my research, I have discovered that the objectivation of the emotion of fear often occurs through the description of facial expressions. Mostly, author's attention is focused on the eyes and actions associated with them: the hero either cries, and the author describes how tears flow down his face, or his eyes seem to "widen". It is also necessary to emphasize the fact that in some cases, James Dashner describes the eyes as an independent body, giving them certain human trades, therefore personifying them, for example, in the following sentences: Chuck stumbled backward, then looked up at Thomas, his eyes so full of fright Thomas felt something shatter in his heart ${ }^{60}$. Or: He glanced behind him at Chuck, standing there with eyes wide ${ }^{60}$. Or: Wide eyes watched him as they walked all the way to the back seat and plopped down; they huddled together $^{60}$. Thomas cried, wept like he'd never wept before. His great, racking sobs echoed through the chamber like the sounds of tortured pain ${ }^{60}$. Tears glistened in his eyes; dribbles of snot oozed from his nostrils ${ }^{60}$. The only sounds were the muffled sobs of Ben, who kept wiping at his nose and eyes $^{60}$. He glanced from boy to boy, begging with his eyes ${ }^{60}$. Newt's eyes narrowed as he looked out toward one of the entrances to the Maze ${ }^{60}$.

One of the peripheral sign of the concept is the connection of fear with a feeling of hatred and disgust. In the novel, Thomas (the main character of the novel) mainly experiences this feeling in relation to the behavior and actions of other Gladers and Grievers: Thomas hated every millisecond of waiting. He just wanted to close his eyes and never see another Griever again $^{60}$. Thomas hated all this talk about punishment, even more than he hated having to keep his mouth shut $26^{61}$. Though Thomas wasn't that afraid of him anymore, he still hated the guy's guts ${ }^{61}$. Minho was still crouched over his backpack on the ground; he glanced up at Thomas with a look of disgust $^{61}$. Their disgusting bodies heaved in and out with mechanical

${ }^{60}$ Dashner J. The Maze Runner. New York, 2009. P. 78, 83, 84, 195, 199, 210, 207, $57,58,65,82$.

${ }^{61}$ Dashner J. The Maze Runner. New York, 2009. P. 92, 119, 192, 199, 18, 25, 30, 45, $47,87,171,210$. 
wheezes of breath ${ }^{61}$. He lifted the spear above his head, braced his feet-felt them sink into the disgusting blubber - then thrust the spear down and into the monster ${ }^{61}$. These examples illustrate the way of mixing the meaning of fear with that of disgust or contempt (cognitive components: mockery, contempt, disgust), which, in its turn, leads to a mocking, satirical attitude to the object. The reason for this connection is the fact that, laughing at the object of his/her fear, the character to some extent receives a psychological release, which safely effects his/her emotional balance.

Furthermore, the perception of pain, soreness, weakness as interdependent unit of fear is rather essential for the work of James Dashner. In the novel, I have found the following expressions of characters' fear: $\mathrm{He}$ felt a rattling pressure of uncertainty, making his head splinter with pain ${ }^{61}$. He stepped on someone's hand, earning a sharp cry of pain in return, then a punch on the calf $f^{61}$. Another stab of pain sliced through Thomas's headthere were too many things to compute at once ${ }^{61}$. Then he felt the jarring dagger of pain as the boy's mouth found a home, bit deeply into Thomas's shoulder ${ }^{61}$. He was limping, his ankle screaming in pain, though he had no memory of hurting $i t^{61}$. Now the boy was in intense pain, going through the same things as Ben ${ }^{61}$. Soreness ate at his joints and muscles ${ }^{61}$. He backed into Teresa, staring as the man dragged the woman away, her legs kicking out weakly, her eyes on Thomas ${ }^{61}$.

As it can be seen from the analyzed examples, the emotional sphere occupies a central role in the English youth dystopian novel "The Maze Runner" by the American author James Dashner. Taking into consideration this fact, the need to study the means of verbalization of the concept of FEAR in youth dystopian novels seems necessary.

\section{CONCLUSIONS}

Having considered theoretical background I have made a conclusion that artistic translation is the translation of works of fiction. It is an instrument of cultural development of the world, the expansion of the collective memory of the mankind, and a factor of culture itself.

Furthermore, artistic translation transforms into a public ownership spiritual and artistic values that are contained in the works of foreign writers. It can be argued that through translation, foreign books become native. However, the translation is not identical to the original and is formed due to numerous transformations of peculiar features of intercultural communication and the subjective translation vision of the conceptual information of the origin.

While translating fictional texts genre diversification plays an important role. It allows to draw conclusions about the uniqueness of the author's thinking and the author's priorities in building an imaginary world. In my study, special attention was paid to the dystopian genre, namely the genre of youth dystopian fiction. 
Having investigated theoretical sources, I have generalized that the term "youth dystopia" is not generally accepted, but is mainly used to catalog books in online libraries. The term is generally used to refer to books for teenagers, although some libraries extend the age range of readers to 21 , noting that most adults are also interested in these novels.

Artistic techniques of modern youth dystopia on the one hand imitate the features of the classic "adult" dystopia, and on the other hand, have a number of specific motives, images and plots. Having considered aspects of the reproduction of the "dystopian canon", I should note that it is not only reproduced in modern texts, but also changes.

One of the main invariant features of the youth dystopian fiction novels is fear which is conceptualized through verbal means chosen by the author. As a practical material for my research I have chosen the novel The Maze Runner by James Dashner.

Having analyzed the means of verbalization of the concept of FEAR in the context of James Dashner's novel The Maze Runner I have come to the following conclusions: most often the author uses the lexeme fear in its first vocabulary meaning (an intensive feeling of horror, shock and disgust) and focuses his attention on the external manifestation of fear, perceived both rationally and emotionally.

The peripheral components of the concept are the interrelation of fear with the feelings of hatred, disgust, and even pain, while the author's attention is often concentrated not only on the expression on the face of a character experiencing the feeling of fear, but on the eyes that convey their condition most sharply and vividly.

Thus, the concept of FEAR in the novel by James Dashner has a unique character, as it is a part of the individual fictional world of the work. Furthermore, the experience of fear is supported by peculiar features of the author's worldview, namely, by his perception of the role of man that he accordingly conveys his youth dystopian novel.

\section{SUMMARY}

The concept of FEAR in the youth dystopian novel The Maze Runner novel by James Dashner has a unique character. It is concluded that the feeling of fear in the novel is reasoned by the peculiarities of the author's worldview. Having analyzed the means of verbalization of the concept of FEAR in the youth dystopian novel The Maze Runner by James Dashner, I have assumed that the most typical use of the nomination of the given concept is the first dictionary meaning, which is the most frequent in the English-speaking environment. I have identified that the external manifestations of the emotion of fear, horror or fright (description of facial expressions, eyes expressions, gestures), as well as such mandatory components of the concept as filling with fear and overcoming it, which are reflected at the lexical and grammatical level are among nuclear features of 
the concept. However, it is proven that the author mostly resorts to the peripheral features of the concept of FEAR, since they are usually individually worked out and thought of by him. It is highlighted that the concept of FEAR is implemented both through separate lexical units and phraseological or metaphorical units, which is a characteristic feature of the James Dashner's individual style. In my research, I have proven that the concept of FEAR in the youth dystopian novel The Maze Runner by James Dashner is inseparably connected with such emotional concepts as HATRED, PAIN, WEAKNESS, DISGUST. In the novel the concept of FEAR is actualized by means of lexical and phraseological units that describe the expression of the eyes of a person who is experiencing fear, which is confirmed by numerous examples in the paper.

\section{REFERENCES}

1. Андронкина Н.М., Голованова Е.Г. Эмоциональные концепты в обучении иноязычному межкультурному общению. Мир науки, культуры, образования. 2012. № 2 (33). С. 28-32. URL: https://cyberleninka.ru/article/n/emotsionalnye-kontsepty-v-obucheniiinoyazychnomu-mezhkulturnomu-obscheniyu/viewer (дата звернення: 18.12.2020).

2. Апресян Ю.Д. Избранные труды. Москва : Школа «Языки русской культуры», 1995. Т. 2. 481 с.

3. Барсукова И.В. Систематизация лингвистических концептов эмоциональных состояний. Вестник Самарского государственного университета. 2008. № 4 (63). С. 13-18. URL: https://cyberleninka.ru/article/n/sistematizatsiya-lingvisticheskihkontseptov-emotsionalnyh-sostoyaniy/viewer (дата звернення: 18.12.2020).

4. Бульбенко Е.С. Базовые составляющие эмоциональных концептов КОВАРТСВО и ХИТРОСТЬ. Известия Волгоградского государственного педагогического университета. 2011. С. 26-29. URL: https://cyberleninka.ru/article/n/bazovye-sostavlyayuschie-emotsionalnyhkontseptov-kovarstvo-i-hitrost/viewer (дата звернення: 18.12.2020).

5. Демьянков В.3. Когниция и понимание текста. Bonpocbl когнитивной лингвистики. 2005. № 3. С. 5-10.

6. Карасик В.И. Языковой круг : личность, концепты, дискурс. Волгоград, 2002. $477 \mathrm{c.}$

7. Красавский Н.А. Концепты СТРАХ и ЖЕСТОКОСТЬ в новелле Франца Кафки «Превращение». Филологические науки. Bonросы теории и практики. 2016. С. 100-103. URL: https://cyberleninka.ru/article/n/kontsepty-strah-i-zhestokost-v-novellefrantsa-kafki-prevraschenie/viewer (дата звернення: 18.12.2020).

8. Красавский Н.А. Эмоциональные концепты в немецкой и русской лингвокультурах. Москва, 2008. 495 с. 
9. Кузнецова Н.В., Перетокина В.А. Лингвистическая реализация концепта НЕНАВИСТЬ. Вестник Нижегородского университета им. Н.И. Лобачевского. 2011. № 6 (2). С. 349-352. URL: https://cyberleninka.ru/article/n/lingvisticheskaya-realizatsiya-kontseptanenavist/viewer (дата звернення: 18.12.2020).

10. Лингвистический энциклопедический словарь. Москва : Советская энциклопедия, 1990. 504 с.

11. Паршин П.Б. Теоретические перевороты и методологический мятеж в лингвистике XX века. Вопросы языкознания. 1996. № 2. C. $19-42$.

12. Попова 3.Д., Стернин И.А. Очерки по когнитивной лингвистике. Москва, 2007. 288 с.

13. Слышкин Г.Г. Лингвокультурные концепты прецедентных текстов. Москва, 2000. $141 \mathrm{c.}$

14. Смурова О.В. Модель лингвистического концепта как композиция функций отображения. Вестник Московского государственного лингвистического университета. 2014. № 25 (711). C. 20-29. URL: https://cyberleninka.ru/article/n/model-lingvisticheskogokontsepta-kak-kompozitsiya-funktsiy-otobrazheniya/viewer(дата звернення:18.12.2020).

15. Солидолова И.А. Проблема моделирования эмоциональных концептов. Вестник Башкирского университета. 2010. URL: https://cyberleninka.ru/article/n/problemy-modelirovaniya-emotsionalnyhkontseptov/viewer (дата звернення: 18.12.2020).

16. Солодуб Ю.П. Современный русский язык : Лексика и фразеология (сопоставительный аспект). Москва, 2002. 259 с.

17. Харченко В.К. Скрытые концепты народных примет. Bonpocbl журналистики, педагогики, языкознания. 2010. № 18 (89). C. 65-72. URL: https://cyberleninka.ru/article/n/skrytye-kontseptynarodnyh-primet/viewer (дата звернення: 18.12.2020).

18. Чезыбаева Н.В. Семантически сопряженные концепты СТРАХ и БЕССТРАШИЕ. Вестник Воронежского государственного университета. 2011. № 1. C. 113-117. URL: https://cyberleninka.ru/article/n/semanticheski-sopryazhennye-kontseptystrah-i-besstrashie/viewer (дата звернення: 18.12.2020).

19. Ченки А. Семантика в когнитивной лингвистике. Фундаментальные направления современной американской лингвистики / под ред. А.А. Кибрика, И.М. Кобозевой, И.А. Секериной. Москва : МГУ, 1997. 369 с.

20. Чесноков И.И. Месть как эмоциональный поведенческий концепт (опыт когнитивно-коммуникативного описания в контексте русской лингвокультуры) : монография. Волгоград : Изд-во ВГПУ «Перемена», 2008. 256 c. 
21. Шафиков С.Г. Любовь : категория или концепт? Языковые $u$ речевые единицы в разных языках. 2006. С. 3-36.

22. Шаховский В.И. Эмоциональные культурные концепты : параллели и константы. Волгоград ; Архангельск. 1996. 1496 с.

23. Шкута О.Г. Вербалізація концепту СТРАХ в англійськомовному молодіжному антиутопічному романі Сюзанни Коллінз "The Hunger Games". Вісник Київського наиіонального лінгвістичного університету. 2019. № 22 (2). С. 79-87. DOI: 10.32589/2311-0821.2.2019.192338.

24. Щербакова И.В. Реализация концепта СTPAX (ANGST) в немецком языке. Символ науки. 2016. № 3. С. 150-152. URL: https://cyberleninka.ru/article/n/semanticheski-sopryazhennye-kontseptystrah-i-besstrashie/viewer (дата звернення: 18.12.2020).

25. Яшкина Е.А. Языковая репрезентация языкового концепта CTPAX в диахроническом аспекте. Наука и современность. 2011. URL: https://cyberleninka.ru/article/n/yazykovaya-reprezentatsiyaemotsionalnogo-kontsepta-strah-v-diahronicheskom-aspekte/viewer (дата звернення: 18.12.2020).

26. Dashner J. The Maze Runner. New York, 2009. 222 c.

27. Kaganovska O.M. Textual concept development in French literary prose: Morphosyntactic aspect. Messenger of Kyiv National Linguistic University. 2019. № 22 (1). P. 45-55. DOI: 10.32589/2311-0821.1.2019.170137.

28. Langacker R.W. A view of linguistic semantics. Topics in Cognitive Linguistics. 1988. P. 49-90.

29. Prihodko G.I. Frame structure of the evaluative utterance. Messenger of Kyiv National Linguistic University. 2019. № 22 (2). P. 114-120. DOI: 10.32589/2311-0821.2.2019.192447.

30. Schwarz M. Einführung in die kognitive Linguistik, überarb. und aktualisierte aufl. Tübingen ; Basel : Francke, 1996. 236 c.

\section{Information about the author:} Shkuta O. H., Lecturer at the Department of English and German Philology and Translation named after Professor I. V. Korunets

Kyiv National Linguistic University 73, Velyka Vasylkivska str., 03150, Kyiv, Ukraine 